\title{
Occluded twice over but lucky: report of concealed macular branch retinal vein occlusion
}

\author{
Srikanta Kumar Padhy, Umesh Chandra Behera ${ }^{\circ}$
}

Retina Vitreous Service, LV Prasad Eye Institute MTC Campus, Bhubaneswar, Orissa, India

\section{Correspondence to} Dr Umesh Chandra Behera, umeshcbehera@gmail.com

Accepted 6 May 2019

\section{DESCRIPTION}

A 56-year-old man presented to our clinic with floaters in right eye for 3 months. The best corrected visual acuity at presentation was $20 / 20$ both eyes (OU). The intraocular pressures were $12 \mathrm{~mm} \mathrm{Hg}$ right eye (OD) and $13 \mathrm{~mm} \mathrm{Hg}$ left eye (OS) with unremarkable anterior segment OU. His past history was suggestive of type 2 diabetes and hypertension of 3 years' duration. Dilated fundus examination OD showed tortuous superotemporal retinal veins, focal venous constriction at the site of occlusion, sclerosed vessels, collaterals, neovascularisation elsewhere (NVE), flame-shaped haemorrhages in the superotemporal periphery and streak preretinal blood at inferotemporal macula (figure 1A). The fundus of left eye revealed features of vascular compensation (a point of focal narrowing of the branch vein with development of collaterals) in superotemporal macula (figure 1B). Fundus fluorescein angiography (FFA) OD revealed delayed filling of occluded retinal vein, areas of capillary non-perfusion, NVE and the presence of collaterals (figure 2A). FFA of left eye confirmed the presence of collaterals and discontinuous foveal avascular zone (FAZ) margin (figure 2B). Optical coherence tomography (OCT) of both eyes was devoid of cystoid macular changes and all the retinal layers were discernible (figure 3A,B). Based on above clinical and imaging findings, a diagnosis of proliferative branch retinal vein occlusion (BRVO) OD and compensated superior macular BRVO OS was made. In view of extensive capillary non-perfusion and neovascularisation, the right eye was treated with superotemporal sectoral laser photocoagulation.

After diabetic retinopathy, retinal venous occlusion constitutes the second most common cause of retinal vascular disease. ${ }^{1}$ Most cases of branch vein occlusion (BVO) are unilateral, however, bilateral BVO was reported in $0.04 \%$ of subjects in a 15 -year follow-up study. ${ }^{2}$ The rate of development of venous

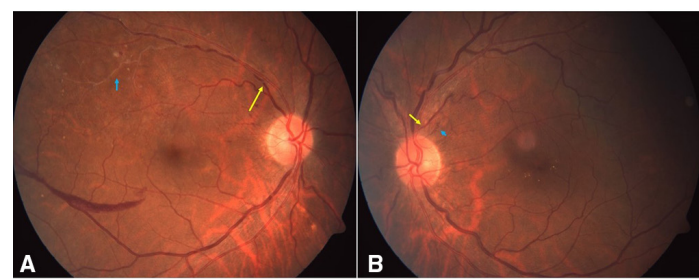

Limited 2019. No commercial re-use. See rights and permissions. Published by BMJ.

To cite: Padhy SK,
Behera UC. BMJ Case
Rep 2019;12:e230740.
doi:10.1136/bcr-2019-
230740

focal narrowing of retinal vein (yellow arrow) with sclerosed vessels (blue arrow) and preretinal blood. (B) Venous occlusive features in left eye (yellow arrow) with development of collaterals (blue arrow) implies

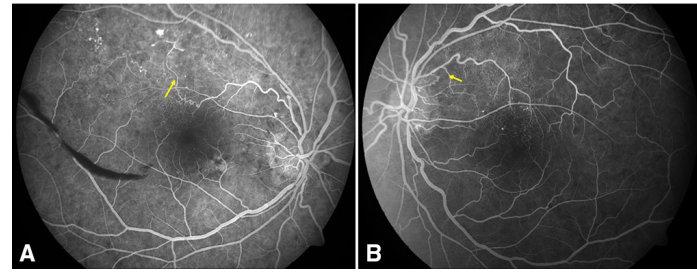

Figure 2 Fundus fluorescein angiography image in venous phase $\mathrm{OU}$ shows branch retinal vein occlusion with collaterals (yellow arrow).

occlusion in the fellow eyes among the unilateral BVO cases was reported to be $1.5 \%$ per year. ${ }^{3}$ Macular BRVO presents with an acute painless blurring of vision and visual field defect when associated with cystoid macular oedema and intraretinal haemorrhage. Floaters due to vitreous haemorrhage may appear late when complicated with neovascularisation. ${ }^{4}$ Spontaneous resolution of macular oedema occurs in about $50 \%$ of patients within a year. ${ }^{5}$ In a study, Hayreh et al reported that after the resolution of macular oedema, visual acuity improved in 58\% of eyes with macular BRVO. ${ }^{5}$ Enlargement and disruption of foveal avascular zone is common to BRVO and most often correspond to vision loss. ${ }^{6}$ In our case fortuitously apart from the FAZ disruption, vision loss was never part of the patient's complaint nor OCT findings were suggestive of macular involvement. We presume that our patient either had no associated macular oedema or had spontaneous resolution of a mild oedema. In the age of early and aggressive treatment of macular oedema in $\mathrm{BVO},{ }^{7}$ the incumbent case stands testimony to the self-limiting course of this disease despite having angiographic evidences of ischaemia.
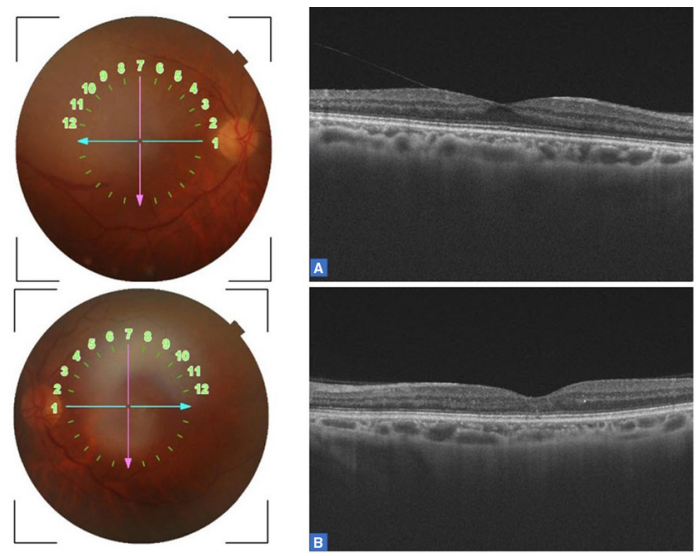
vascular compensation.
Figure 3 Optical coherence tomography of right (A) and left eye (B) shows normal retinal architecture. 


\section{Patient's perspective}

I am happy that my disease could be diagnosed at early stages and appropriate treatment was given to prevent future complications.

\section{Learning points}

- Detailed dilated fundus examination is mandatory in the fellow eye of the eyes with retinal venous occlusion. If in doubt, fundus fluorescein angiography is recommended.

- Branch vein occlusion study inferred that macular oedema secondary to BVO recovers spontaneously in 37\% of subjects.

- In cases with mild vision loss observation alone may not lead to major vision impairment.

Contributors SKP was involved in conceptualising, data acquisition, manuscript writing and reviewing it critically. UCB was involved in planning, conducting, analysis, data interpretation and critically reviewing the manuscript.
Funding The authors have not declared a specific grant for this research from any funding agency in the public, commercial or not-for-profit sectors.

Competing interests None declared.

Patient consent for publication Obtained.

Provenance and peer review Not commissioned; externally peer reviewed.

\section{REFERENCES}

1 Jaulim A, Ahmed B, Khanam T, et al. Branch retinal vein occlusion: epidemiology, pathogenesis, risk factors, clinical features, diagnosis, and complications. An update of the literature. Retina 2013:33:901-10.

2 Klein R, Moss SE, Meuer SM, et al. The 15-year cumulative incidence of retinal vein occlusion: the Beaver Dam Eye Study. Arch Ophthalmol 2008;126:513-8.

3 Brown G, Yoo J, Brown M, et al. The Burden of Retinal Venous Occlusion: An Assessment of Fellow Eyes in 1000 Cases. Ophthalmol Retina 2017;1:404-12.

4 Scruggs BA, Quist TS, Kravchuk 0, et al. Branch retinal vein occlusion. 2018 https:// EyeRounds.org/cases/274-branch-retinal-vein-occlusion.htm.

5 Hayreh SS, Zimmerman MB, Bridget Zimmerman M. Branch retinal vein occlusion: natural history of visual outcome. JAMA Ophthalmol 2014;132:13-22.

6 Parodi MB, Visintin F, Della Rupe $\mathrm{P}$, et al. Foveal avascular zone in macular branch retinal vein occlusion. Int Ophthalmol 1995;19:25-8.

7 Clark WL, Boyer DS, Heier JS, et al. Intravitreal Aflibercept for Macular Edema Following Branch Retinal Vein Occlusion: 52-Week Results of the VIBRANT Study. Ophthalmology 2016;123:330-6.

Copyright 2019 BMJ Publishing Group. All rights reserved. For permission to reuse any of this content visit https://www.bmj.com/company/products-services/rights-and-licensing/permissions/

BMJ Case Report Fellows may re-use this article for personal use and teaching without any further permission.

Become a Fellow of BMJ Case Reports today and you can:

- Submit as many cases as you like

- Enjoy fast sympathetic peer review and rapid publication of accepted articles

- Access all the published articles

- Re-use any of the published material for personal use and teaching without further permission

For information on Institutional Fellowships contact consortiasales@bmjgroup.com

Visit casereports.bmj.com for more articles like this and to become a Fellow 